\title{
STUDI KRITIS HADITS-HADITS \\ KEPEMIMPINAN (IMAMAH) DUA BELAS IMAM DALAM LITERATUR HADITS SUNNI
}

\author{
Muhammad Zaki
}

Dosen PPs UIN Raden Intan Lampung

email: muhammad.zaki266@yahoo.co.id

Diterima: 26 November 2016. Disetujui: 03 Februari 2017

Dipublikasikan: Mei 2017

\begin{abstract}
The imamah (leadership) of twelve imams is considered as a concept coming from Shi'ite tradition. Hadith literature of Sunni, however, has numerous hadith on imamah as exemplified by Shahih Bukhari, Muslim, Sunan Abi Dawud, al-Tirmidzi, al-Nasa'i, Ibn Majah, and Musnad Imam Ahmad. Although these hadith have some differences in terms of their structure, the hadith have in common in their meaning and substance. Sunni scholars consider the quality of transmitters and content of hadith on twelve imams is shahih. In contrast, Shi'ite scholars do not consider them as mutawatir. Sunni scholars of hadith are not in agreement in determining the figures considered as a twelve imam. However, they agree that all the twelve imams were from Quraish tribe and sworn in by ummah. The restriction of some imams to twelve is not absolute since there is a hadith stating that the number of imam and caliphate would emerge after the death of the Prophet saw. Muslim were obliged to put their loyalty on and obey them. The name of twelve imams derives from the fact that during their leadership, Muslims achieved the glorious period in terms of religious, scientific and political field.
\end{abstract}

Keywords: Imamah, Dua Belas Imam, Literatur Hadits Sunni 


\section{A. Pendahuluan}

Sunni dan Syiah merupakan kelompok terbesar dalam tubuh umat Islam yang memiliki akar sejarah peradaban yang panjang. Meskipun sudah menorehkan nilai-nilai peradaban, dalam perjalanan sejarahnya seringkali terjadi benturan antara keduanya. Hal ini disebabkan banyaknya perbedaanperbedaan, baik perbedaan yang prinsip maupun yang tidak prinsip. Di antara perbedaan yang paling prinsip antara Sunni dan Syiah adalah persoalan kepemimpinan atau imamab ${ }^{1}$ (selanjutnya disebut imamah) setelah Nabi saw wafat.

Masalah imamah menjadi doktrin fundamental dalam mazhab Syiah, baik Syiah Imamiyah, Zaidiyah, maupun Ismailiyah. $^{2}$ Problematika imamah telah menjadi bahan perdebatan berabad-abad bahkan pertentangan mazhab Syiah dengan kelompok lainnya di kalangan kaum muslimin. Syiah Imamiyah (Syiah terbesar pengikutnya) meyakini bahwa sepeninggal Nabi saw kepemimpinan umat atau khilafah seharusnya berada di tangan keluarga Nabi saw (Ahlul Bait) terdekat yaitu Ali dan keturunannya (Dua Belas Imam). Keyakinan ini berdasarkan nas-nas Hadits yang diyakini kelompok Syiah sebagai Hadits yang sahih bahkan mutawatir. Di antara nas yang paling jelas mengenai hak Ali terhadap imamah atau khilafah adalah Hadits yang diucapkan Nabi ketika berada di suatu tempat bernama Ghadir Khum, setelah menunaikan haji wada'. Teks Hadits tersebut adalah: "Barangsiapa yang menjadikan aku sebagai walinya maka hendaklah

1Ajaran yang sentral dan mutlak diyakini dalam Syiah adalah doktrin Imamah. Imamah menurut bahasa adalah "kepemimpinan", sedangkan imam artinya pemimpin, yang secara generik dapat digunakan untuk pemimpin yang baik dan yang buruk. Namun dalam pengertian Syiah (Itsna Asyariyah) imamah merupakan doktrin primer dalam teologi dan ideologi. Lihat Muhammad Baharun dalam "Dari Imamah sampai Mut'ah", Malang, Pustaka Bayan, 2008, h. 30

2Syiah Imamiyah berkeyakinan hak imamah berada pada Musa ibn Ja'far al-Shadiq beserta keturunannya, Syiah Zaidiyah berkeyakinan hak imamah pada Imam Zaid bin Ali dan keturunannya, sedangkan Syiah Ismailiyah berkeyakinan hak imamah pada Ismail bin Ja'far al-Shadiq. 
ia menjadikan Ali sebagai walinya. Ya Allah, lindungilah mereka yang berwali kepadanya dan musubilab mereka yang memusubinya.". 3

Selain diriwayatkan dalam sumber-sumber Hadits Syiah sendiri, Hadits-Hadits tentang Dua Belas Imam juga ternyata diriwayatkan dan dibukukan dalam kitab-kitab Hadits Sunni. Hal inilah yang membuat Syiah lebih merasa yakin bahwa persoalan imamah itu benar adanya dan merupakan rukun dalam akidah umat ini, karena dalam literatur kedua mazhab Hadits-Hadits Imam Dua Belas banyak diriwayatkan dan disepakati kesahihannya, bahkan dalam kitab-kitab Hadits Sunni yang muktabar seperti Shahih al-Bukhari dan Shabih Muslim.

Ini menunjukkan bahwa konsep Dua Belas Imam bukanlah hal baru dan dominasi kelompok Syiah. Meskipun dalam Hadits tersebut (literatur Sunni) tidak disebutkan nama-nama imam satu persatu sebagaimana Hadits Syiah, namun itu cukup mengindikasikan bahwa konsep imamah Dua Belas Imam memiliki sumber dalil yang valid dan sulit dibantah. Menariknya, dalam beberapa literatur Sunni, ketika menerangkan Hadits Dua Belas Imam, di antara ulama Sunni ada yang menyebutkan nama-nama imam versi Syiah, seperti Ibn Hajar al-Haitami dalam al-Shawa'iq al-Mubriqah, alQunduzi al-Hanafi dalam Yanabi' al-Mawaddah, dan Ibn Sabbagh al-Maliki dalam kitabnya Fushul al-Mubimmah fi Ma'rifat al-Aimmah.

Tercantumnya Hadits-Hadits Dua Belas Imam dalam literatur Sunni semakin memperkuat argumentasi kelompok Syiah, bahwa doktrin imamah merupakan suatu keniscayaan. Dengan demikian --menurut Syiah-- suksesi khilafah Abu Bakar, Umar, dan Usman telah menyalahi sunnah atau petunjuk Nabi saw. karena mengabaikan hak-hak Ali dan keturunannya. Mempertanyakan validitas Hadits-Hadits tersebut atau sumbernya artinya tidak konsekuen dengan

${ }^{3}$ Hadits ini juga telah diriwayatkan dalam literatur Hadits Sunni seperti Sunan al-Tirmidri, 
slogan yang populer dalam tradisi Hadits Sunni, bahwa kitab Shahih al-Bukhari merupakan kitab tersahih setelah al-Qur'an dan kitab Shabih Muslim merupakan kitab Hadits yang memiliki validitas tinggi dibanding kitab Hadits lainnya. Para ulama Hadits Sunni tentunya memiliki sikap obyektif dalam periwayatan Hadits $^{4}$ yang tentunya pasti memiliki alasan mencantumkan Hadits-Hadits tersebut dalam kitab mereka dan bagaimana penafsiran mengenai imamah Dua Belas Imam tersebut.

Bagaimana redaksi teks-teks Hadits Dua Belas Imam dalam kitab Hadits Sunni? Bagaimana kualitas Hadits tersebut? Jika kualitasnya shahib bagaimana sikap ulama Sunni dalam memahaminya? Inilah yang menjadi persoalan yang akan dikaji dalam tulisan ini.

\section{B. Pembahasan}

\section{Pengertian Imamah}

a. Al-Mawardi: "Imamah itu ditetapkan untuk menggantikan tugas kenabian dalam menjaga agama dan menata dunia dengannya". 5

b. Al-Taftazani: "Imamah ialah kepemimpinan masyarakat seperti khalifah dan penerus Rasulullah dalam urusan agama dan sosial".

c. Ibn Khaldun: "Imamah adalah mengatur seluruh umat berdasarkan syariat dalam mewujudkan maslahat mereka yang bersifat ukhrawi an duniawi yang akan kembali kepada ukhrawi. Pada hakikatnya

${ }^{4}$ Ulama Hadits Sunni memiliki tingkat obyektivitas yang tinggi dalam periwayatan Hadits. Mereka akan menerima suatu Hadits jika sudah lolos uji melalui seperangkat metode penyaringan Hadits yaitu kritik sanad dan matan berdasarkan kaidah kesahihan Hadits. Meskipun perawi Hadits tersebut berasal dari luar kelompok Sunni, seperti Syiah, Khawarij, Mu’tazilah, Qadariah, Jabariyah, dan lain-lain, jika memenuhi syarat-syarat tersebut maka Haditsnya diterima.

${ }^{5} \mathrm{Abu}$ al-Hasan Ali al-Mawardi, Abkam al-Sulthaniyah wa al-Wilayat alDiniyah, (Kairo, Syirkah al-Quds, 2014 M), h. 31 
imamah ialah pengganti dari pemiliki syariaat dalam menjaga agama dan menata dunia dengan agama".6

Dari defenisi para ulama di atas dapat disimpulkan, bahwa imamah adalah kepemimpinan dalam rangka meneruskan tugas kenabian untuk mewujudkan maslahat ukhrawi dan duniawi.

Untuk membedakan antara imamahdalam salat dengan imamah di atas maka dimunculkanlah istilah imamah al-kubra dan imamah al-sughra. Jika imamah disebut secara mutlak atau umum maka yang dimaksud adalah imamabal-kubra atau aluгma. Imamahsughra adalah imamah dalam salat atau kepemimpinan seorang suami atas keluarganya.

Selain istilah imam digunakan juga istilah khalifah dan amirul mu'minin. Kedua istilah itu bersinonim dengan istilah imam. Sebagaimana yang dikatakan oleh Imam al-Nawawi: "Seorang imam boleh disebut khalifah, imam, dan amirul mukminin". Ibn Khaldun menyatakan: "Hakikat kedudukan ini sudah kami jelaskan sebelumnya, bahwa imamah adalah wakil dari pemilik syariat dalam hal menjaga agama dan mengatur dunia, maka ia disebut khilafah dan imamah. Sedangkan orang yang melaksanakannya disebut khalifah dan imam. Ibn al-Manzhur menyamakan khilafah dengan imarah (pemerintahan). ${ }^{7}$ Pendapat yang cukup jelas dalam hal ini adalah yang dikemukakan oleh Abu Zahrah: "Aliran-aliran politik secara keseluruhan berporos pada khilafah yang merupakan kepemimpinan tertinggi. Disebut khalifah karena orang yang menjabatnya dan menjadi pemimpin tertinggi kaum muslimin, posisinya adalah menggantikan Nabi saw dalam hal mengatur segala urusan mereka. Dan khilafah disebut imamah karena khalifah juga disebut imam. Alasan

'Ibn Khaldun, al-Muqaddimah, (Dar al-Baz li al-Ansyr wa al-Tauzi', 1398 H), h. 190

${ }^{7}$ Abd Allah al-Dumaiji, Konsep Kepemimpinan Dalam Islam, terj. Umar Mujtahid, judul asli "al-Imamah al-Uzhma inda Abl al-Sunnah wa al-Jamaah, Jakarta, Ummul Qura, 1437 H/2016 M, h. 44 
lainnya karena umat mengikui di belakangnya sebagaimana umat salat di belakang seseorang imam yang mengimami mereka". 8

Orang yang pertama kali disebut amirul mukmimin adalah Umar ibn al-Khattab ra. Sebenarnya istilah amir sudah pernah digunakan di zaman Nabi saw namun tidak digunakan untuk menyebut khalifah. Istilah amir digunakan untuk menyebut para komandan satuan-satuan tempur, pemimpinpemimpin wilayah atau daerah, perkotaaan dan semacamnya. Sebagaimana sabda Nabi saw: "Siapa yang taat kepadaku maka ia telah taat pada Allah siapa yang durhaka padaku maka ia durhaka pada Allah. Siapa yang taat pada amirku maka ia telah taat padaku, dan siapa yang durhaka pada amirku maka ia telah durhaka padaku."9

Dalam sejarahnya penggunaan istilah khilafah dan imamah mengalami perbedaan sesuai dengan siapa yang menggunakannya. Di kalangan Ahlussunnah kata imamahdigunakan dalam tema-tema akidah dan fikih, sementara kata khilafah umumnya digunakan dalam tulisantulisan tentang sejarah dan politik. Sehingga ulama atau tokoh-tokoh Islam yang memiliki reputasi di bidang keilmuan, moral, intelektual dan spiritual dan banyak pengikutnya disebut imam seperti Imam Mazhab Empat, Imam al-Haramain, Imam al-Ghazali, Imam al-Nawawi, dan lain-lain. Adapun yang menduduki jabatan politik atau pemerintahan disebut khalifah, seperti para Khalifah Bani Umayyah dan Khalifah Bani Abbasiyah.

Ini juga yang dianut oleh kelompok Syiah.Kelompok Syiah menggunakan kata imamah, bukan khilafah. Mereka menganggap imamah sebagai salah satu rukun iman. Mereka membedakan antara imamah dan khilafah. Menurut mereka imamah sebagai kepemimpinan agama dan khilafah sebagai

${ }^{8} \mathrm{Abu}$ Zahrah, Tarikh al-Madzahib al-Islamiyah, Kairo, Dar al-Fkr alArabi, 1430 H/2010 M., h. 25

${ }^{9}$ Hadits riwayat al-Bukhari 
kepemimpinan negara. Inilah yang membuat istilah imamah terkesan didominasi oleh Syiah.

\section{Eksistensi Imamah dalam Kehidupan}

Imamah sangat penting keberadaannya, karena dengan adanya imamah dapat menjamin keteraturan sistem kehidupan masyarakat. Oleh sebab itu, mayoritas kaum muslimin menyepakati kewajiban mengangkat seorang imam atau pemimpin. Tidak ada yang menyelisihi ijma' ini selain sekte Najdat dari kalangan Khawarij, Al-'Asham, dan Al-Futhi dari kalangan Mu'tazilah. ${ }^{10}$

Terkait kewajiban imamah, Ibnu Hazm menuturkan, Ahlus Sunnah wal Jamaah, seluruh kelompok Murji'ah, seluruh kelompok Syiah dan seluruh kelompok Khawarij menyepakati kewajiban imamah, dan umat wajib tunduk pada imam yang adil yang menegakkan hukum-hukum Allah di antara mereka, memimpin mereka berdasarkan hukumhukum syariat yang disampaikan Rasulullah, kecuali sekte Najdat dari kelompok Khawarij. Mereka menyatakan bahwa imamah tidak diwajibkan bagi kaum muslimin. Mereka hanya diwajibkan menjalankan kebenaran. ${ }^{11}$ Al-Qurthubi menuturkan, "Tidak ada perbedaaan pendapat terkait wajibnya imamah di antara umat ataupun di antara para imam, selain pendapat yang diriwayatkan dari Asham, karena ia 'asham (tuli) sehingga tidak bisa mendengar syariat. Demikian halnya kalangan lain yang menyatakan seperti pernyataannya, mengikuti pendapat dari mazhabnya ". 12

Kalangan yang mewajibkan imamah berpendapat bahwa kewajiban ini bersumber dari syariat. Mereka adalah Ahlus Sunnah wal Jamaah dan sebagian besar kalangan Mu'tazilah. Sebagian lainnnya mewajibkan imamah berdasarkan akal.Dalil lainnya tentang wajibnya imamah adalah kaidah syar'i yang menyatakan bahwa ketika suatu kewajiban

${ }^{10}$ Al-Dumaiji, Op. Cit., h. 55

${ }^{11}$ Ibid. h. 56

${ }^{12}$ Ibid. 
tidak terlaksana tanpa sesuatu maka sesuatu tersebut hukumnya wajib. Sudah maklum bahwa Allah telah memerintahkan banyak hal yang tidak akan mampu dilaksanakan oleh individu. Misalnya, menegakkan budud, mempersiapkan pasukan mujahidin untuk menyebarkan dan membela agama, meninggikan kalimat Allah, menarik dan membagikan zakat kepada golongan yang telah ditentukan, menjaga wilayah kaum muslimin, menyebarkan keadilan, mencegah kezaliman, memutuskan pertikaian di antara sesama manusia, dan kewajiban-kewajiban lain yang tidak dapat dilaksanakan oleh secara individual. Semua kewajiban tersebut (agar terlaksana) mengharuskan adanya kekuasaan dan kekuatan yang berhak ditaati oleh semua individu. Sebuah kekuasaan yang mampu dan berwenang melaksanakan kewajiban-kewajiabn tersebut. Kekuasaan yang dimaksud adalah imamah.

Oleh sebab itu, wajib hukumnya menunjuk seorang imam yang dipatuhi dan ditaaati. Imam yang memiliki wewenang untuk mengatur segala persoalan, agar ia dapat melaksanakan kewajiban-kewajiban tersebut. Terkait hal ini, Amirul Mukminin Ali bin Abi Thalib berkata " Umat manusia harus memiliki emirat (pemerintahan) entah itu baik ataupun jahat." Orang-orang pun bertanya, "Wahai Amirul Mukminin, tentang pemerintahan yang baik bisa kami maklum. Tapi bagaimana dengan pemerintahan yang jahat?" Ia menjawab, "Untuk melaksanakan budud, mengamankan jalan-jalan, memerangi musuh, dan membagi fai"."'13

Menurut Ibn Taimiyah, wajib diketahui bahwa memimpin urusan umat termasuk salah satu kewajiban agama yang terbesar, bahkan agama tidak bisa ditegakkan tanpanya. Sesungguhnya, maslahat seluruh umat manusia tidak sapat terlaksana kecuali dengan berkumpul, karena satu sama lain saling membutuhkan. Alasannya adalah karena Allah mewajibkan amar makruf dan nahi munkar. Perintah ini tidak 
dapat terlaksana tanpa adanya kekuatan dan kekusaan. Demikian halnya kewajiban-kewajiban lain yang Allah perintahkan, seperti jihad, berlaku adil, pelaksanaan haji, shalat berjamaah, shalat 'Id, menolong orang yang teraniaya, menegakkan hudud, dan lain sebagainya. Semua itu tidak bisa dilaksanakan tanpa adanya kekuatan dan kekuasaan. ${ }^{14}$

Argumentasi lain tentang kewajiban imamah adalah bahwa kecenderungan untuk mengangkat seorang pemimpin merupakan fitrah, di mana Allah menciptakan manusia sesuai dengan fitrah tersebut. Manusia adalah makhluk madani (beradab), maka jelas ia tidak dapat hidup sendirian, terpisah dari manusia lainnya. Bahkan, ia harus hidup bersama dengan manusia lain agar persoalan-persoalan hidup dapat berjalan dengan baik dan segala kepentingannya terlaksana. Dan dampak dari hidup berbaur dengan sesama ialah terjadi benturan kepentingan dan menyebabkan gesekan antara satu sama lain sehingga menimbulkan pertikaian. Untuk itu, diperlukan seorang pemimpin sebagai rujukan ketika terjadi perselisihan di antara sesama manusia.

\section{Hadits-Hadits tentang Dua Belas Imam dalam Literatur Sunni}

Untuk mengetahui teks-teks Hadits tentang Dua Belas Imam dalam literatur Hadits Sunni, penulis melakukan takhrij" menggunakan kitab al-Mu'jam al-Mufahras li Alfazhb alHadits al-Nabawi. Dengan menelusuri kata kunci "khalifah" dan "amir", didapatkan data bahwa Hadits tersebut terdapat di kitab Shahih al-Bukhari satu riwayat, Shahih Muslim enam riwayat, Sunan Abu Dawud dua riwayat, Sunan al-Tirmidzi satu riwayat, dan Musnad Imam Abmad 15 riwayat. Bahkan ada yang mencatat terdapat 34 riwayat dari Imam Ahmad mengenai

\footnotetext{
${ }^{14} \mathrm{Ibn}$ Taimiyah, al-Siyasah al-Syar'iyah, (Beirut: Dar al-Kutub al-Islami, 1969 M), Cet. IV, h. 162

${ }^{15}$ Takbrij yang penulis maksudkan di sini adalah takbrij dalam pengertian menunjukkan asal usul Hadits dan mengemukakan sumber pengambilannya dari berbagai kitab Hadits yang disusun mukharrij-nya langsung.
} 
Hadits ini. Sebenarnya selain dari kitab-kitab Hadits di atas masih banyak kitab Hadits lainnya mencantumkan riwayat tentang Dua Belas Imam, seperti al-Mustadrak, Shahib Ibn Hibban, Mu'jam al-Tabrani, Musnad al-Bazzar, dan lain-lain.

Berikut ini teks-teks Hadits tentang Dua Belas Imam lengkap dengan sanad-nya dari kitab-kitab Hadits di atas:

\section{Kitab Shabih al-Bukhari}

Dalam kitab Shabih al-Bukharipada kitab alAbkambabal-Istikhlaf, Hadits ke 51 dengan satu jalur sanad:16

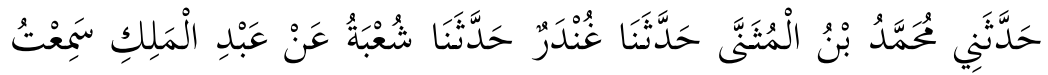

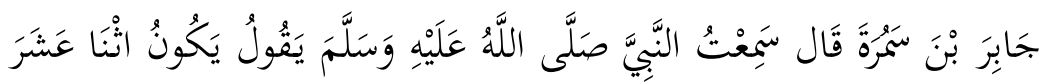

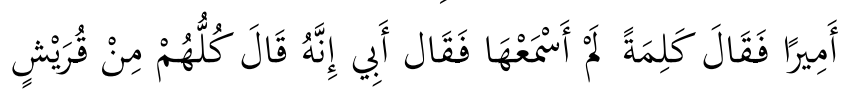

Artinya:

"Telah menceritakan kepadaku Muhammad bin al-Mutsanna; telah menceritakan kepada kami Ghundar; telah menceritakan kepada kami Syu'bah; dari Abdul Malik; aku mendengar Jabir bin Samurah mengataka; aku mendengar Nabi shallallahu 'alaihi wasallam bersabda; "Akan muncul dua belas pemimpin", Kemudian beliau mengucapkan kalimat yang tidak dapat kami dengar, maka ayahku berkata, beliau mengatakan: "Kesemuanya dari Quraisy."

\section{Kitab Shabih Muslim}

Dalam kitab Shabih Muslim, kitab al-Imarah, terdapat enam buah Hadits dengan sanad berbeda sebagai berikut ${ }^{17}$ :

${ }^{16} \mathrm{Abu}$ Abdillah Muhammad bin Ismail al-Bukhari, Shabih al-Bukhari, (Semarang: Toha Putra, 1401 H/1981 M), juz VIII, h. 127

${ }^{17}$ Lihat Abu al-Husain Muslim bin al-Hajjaj, Shabih Muslim bi Syarh alNawawi, (Indonesia: Maktabah Dahlan, t.th.), Jilid III, h. 1452-1453 


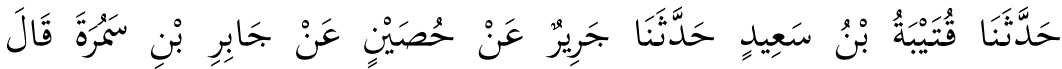

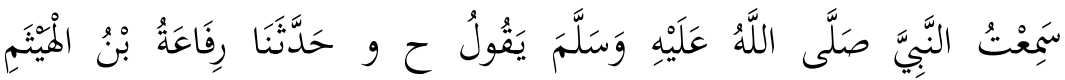

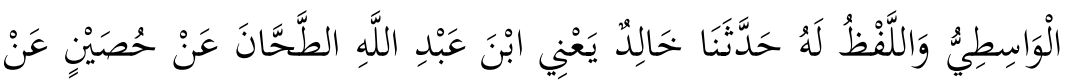

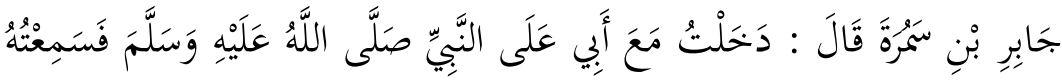

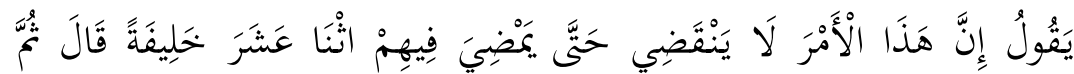

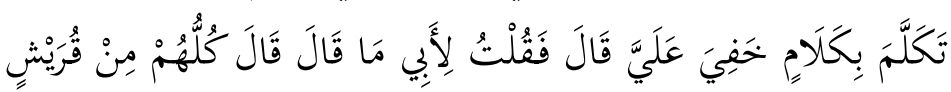

Artinya:

"Telah menceritakan kepada kami Qutaibah bin Sa'id telah menceritakan kepada kami Jarir dari Hushain dari Jabir bin Samurah dia berkata, "Rasulullah shallallahu 'alaihi wasallam bersabda. (dalam jalur lain disebutkan) Telah menceritakan kepada kami Rifa'ah bin Al-Haitsam Al Wasithi sedangkan lafadznya dari dia, telah menceritakan kepada kami Khalid -yaitu Ibnu Abdullah At Thahan-- dari Hushain dari Jabir bin Samurah dia berkata, "Aku pernah menemui Nabi shallallahu 'alaihi wasallam bersama dengan ayahku, maka aku mendengar beliau bersabda: "Sesungguhnya pemerintahan ini tidak akan runtuh hingga kedua belas orang khalifah memerintah.” Kemudian beliau mengucapkan kata-kata yang kurang jelas bagiku, Jabir berkata, "Lalu aku bertanya kepada ayahku, "Apa yang dikatakan beliau? ayahku menjawab, "(beliau mengatakan) Semuanya dari bangsa Quraisy."

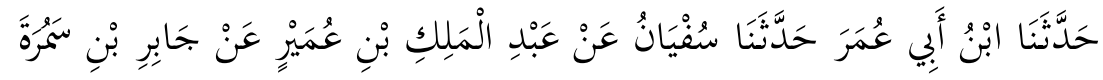

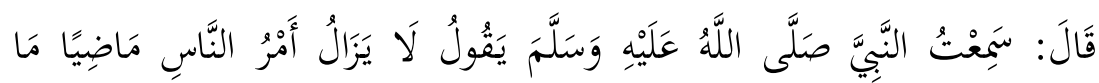

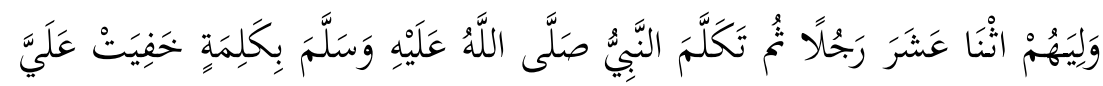

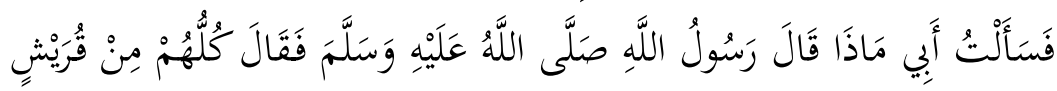


Artinya:

"Telah menceritakan kepada kami Ibnu Abu Umar; telah menceritakan kepada kami Sufyan dari; Abdul Malik bin 'Umair dari Jabir bin Samurah dia berkata, "Aku mendengar Nabi shallallahu 'alaihi wasallam bersabda: "Perkara manusia akan tetap berlalu (jaya) selagi mereka masih tetap diperintahkan oleh dua belas orang laki-laki." Kemudian Nabi shallallahu 'alaihi wasallam mengucapkan kata-kata yang tidak jelas bagiku, maka aku bertanya kepada ayahku, "Apa yang dikatakan oleh Rasulullah shallallahu 'alaihi wasallam?” Beliau menjawab, "Mereka semua dari Quraisy."

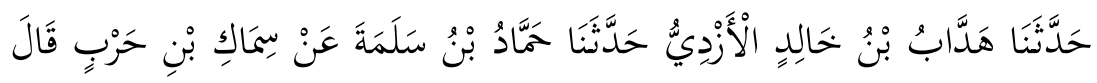

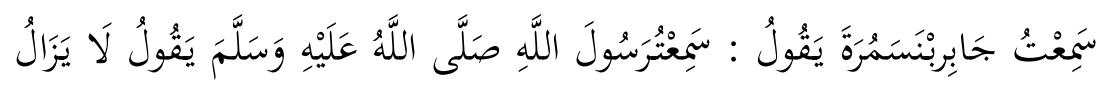

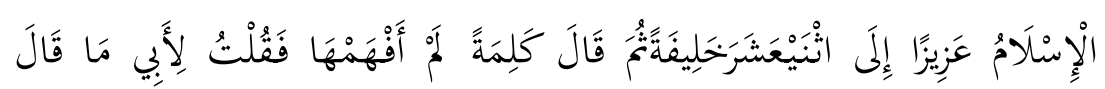

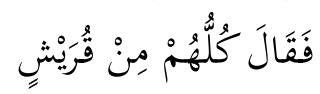

Artinya:

"Telah menceritakan kepada kami Haddab bin Khalid alAzdi; telah menceritakan kepada kami Hammad bin Salamah dari Simak bin Harb dia berkata:"Aku mendengar Jabir bin Samurah berkata, "Aku mendengar Rasulullah shallallahu 'alaihi wasallam bersabda: "Islam senantiasa kuat dan berkuasa sampai kedua belas khalifah." Kemudian beliau mengucapkan kata-kata yang tidak aku pahami, lantas aku bertanya kepada ayahku, "Apa yang dikatakan beliau?" dia menjawab, "Mereka semua dari bangsa Quraisy."

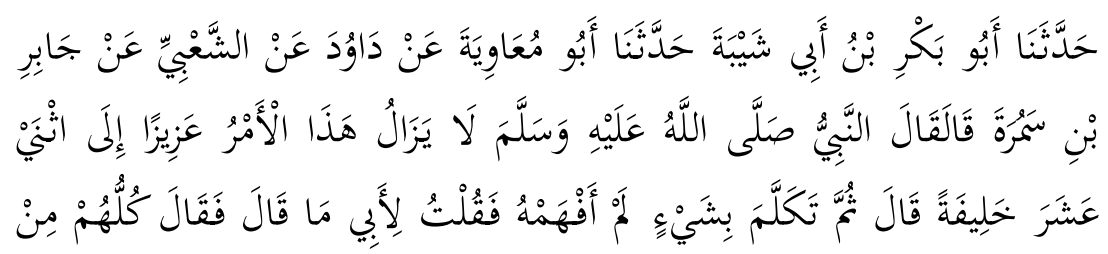


Artinya:

"Telah menceritakan kepada kami Abu Bakar bin Abu Syaibah; telah menceritakan kepada kami Abu Mu'awiyah; dari Dawd dari As Sya'bi dari Jabir bin Samurah dia berkata: Nabi shallallahu 'alaihi wasallam bersabda:"Perkara (kepemimpinan) ini akan senantiasa kuat sampai kedua belas khalifah (pemimpin)." Jabir berkata, "Kemudian beliau mengucapkan kata-kata yang tidak aku pahami, maka aku bertanya kepada ayahku, "Apa yang dikatakan beliau? Beliau menjawab, "Mereka semua dari bangsa Quraisy."

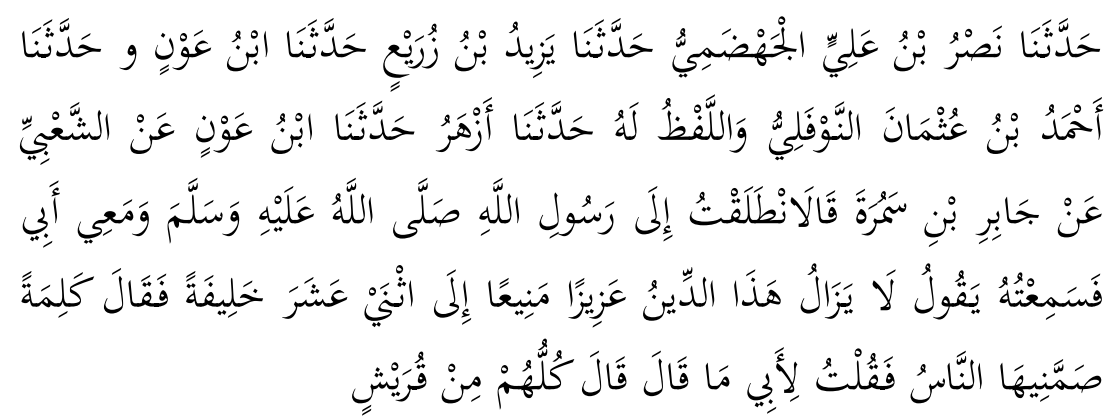

Artinya:

"Telah menceritakan kepada kami Nahsr bin Ali Al Jahdhami; telah menceritakan kepada kami Yazid bin Zurai'; telah menceritakan kepada kami Ibnu 'Aun; (dalam jalur lain disebutkan) telah menceritakan kepada kami Ahmad bin Utsman An Naufali sedangkan lafadznya dari dia; telah menceritakan kepada kami Azhar; telah menceritakan kepada kami Ibnu 'Aun dari Asy Sya'bi; dari Jabir bin Samurah dia berkata, "Aku pernah datang kepada Rasulullah shallallahu 'alaihi wasallam bersama dengan ayahku, lalu aku mendengar beliau bersabda: "Agama ini akan senantiasa kuat dan kokoh hingga kedua belas khalifah (pemimpin)." Kemudian beliau mengucapkan kata-kata yang lirih hingga tidak terdengar oleh orang-orang, maka aku bertanya kepada ayahku: "Apa yang dikatakan beliau?" beliau menjawab: "Mereka semua dari suku Quraisy.” 


\section{Kitab Sunan Abi Dawud}

Dalam kitab Sunan Abi Dawud, kitab al-Mabdi, terdapat tiga riwayat sebagai berikut: ${ }^{18}$

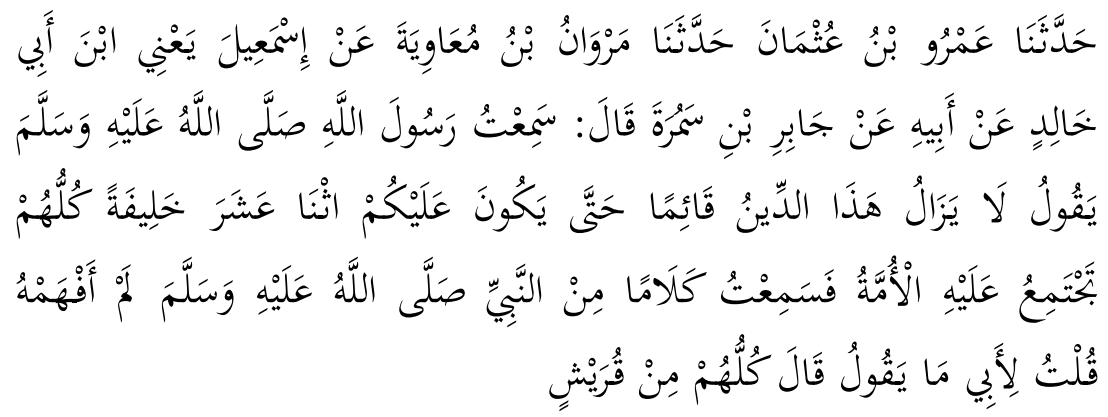

Artinya:

"Telah menceritakan kepada kami Amru bin Utsman berkata; telah menceritakan kepada kami Marwan bin Mu'awiyah; dari Isma'il --maksudnya Ismail bin Abu Khalid--; dari Bapaknya dari Jabir bin Samurah ia berkata: "Aku mendengar Rasulullah shallallahu 'alaihi wasallam bersabda: "Agama ini akan senantiasa tegak hingga muncul di antara kalian dua belas khalifah, dan manusia akan ikut bersama mereka." Aku mendengar ucapan dari Nabi shallallahu 'alaihi wasallam yang tidak aku mengerti, lalu aku bertanya pada bapakku tentang apa yang beliau katakan itu, ia (bapakku) menjawab, "Mereka semua (para khalifah) dari bangsa Quraisy.”

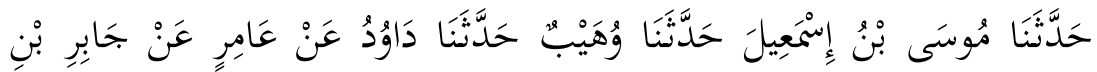

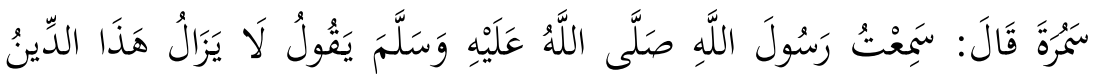

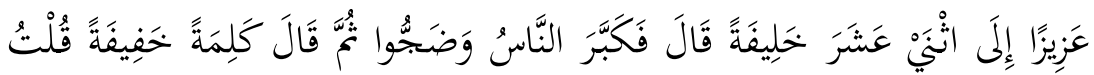

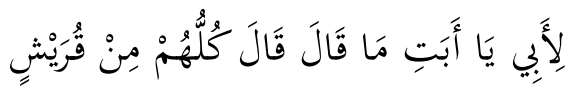

18 Abu Dawud Sulaiman ibn al-Asy'ats al-Sijistani, Sunan Abi Dawud, Beirut, dar al-Fikr, 1414 H/1994 M, jilid II, h. 314 
Artinya:

"Telah menceritakan kepada kami Musa bin Isma'il; telah menceritakan kepada kami Wuhaib; telah menceritakan kepada kami Dawud dari Amir dari Jabir bin Samurah; "Aku mendengar Rasulullah shallallahu 'alaihi wasallam bersabda: "Agama ini akan tetap mulia hingga khalifah ke dua belas." Jabir berkata: "Orang-orang bertakbir dan berteriak. Kemudian beliau mengatakan suatu ucapan yang pelan (hingga aku tidak mendengarnya, lalu aku bertanya kepada bapakku, "Wahai bapakku, apa yang beliau katakan?" Ia menjawab, "Beliau mengatakan bahwa mereka dari bangsa Quraisy."

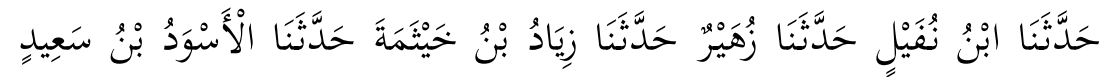

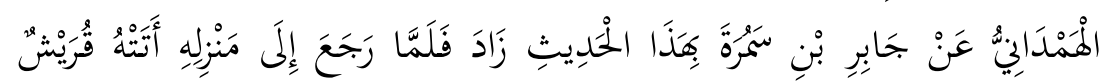

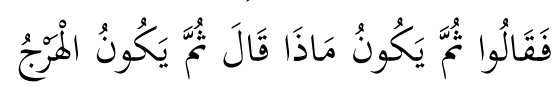

Artinya:

"Telah menceritakan kepada kami Ibnu Nufail; telah menceritakan kepada kami Zuhair; telah menceritakan kepada kami Ziyad bin Khaitsamah; telah menceritakan kepada kami Al Aswad bin Sa'id Al Hamdani; dari Jabir bin Samurah dengan hadits yang sama. Namun ia menambahkan, "Ketika beliau kembali ke rumahnya, orang-orang Quraisy mendatanginya seraya bertanya, "Setelah itu apa yang akan terjadi ?" Ia menjawab: "Akan terjadi pembunuhan."

\section{Kitab Sunan al-Tirmidzi}

Al-Tirmidzi meriwayatkan dalam kitabnya pada kitab al-Fitan, bab “Ma Ja'a fi al-Khulafa' sebuah Hadits berikut ini:

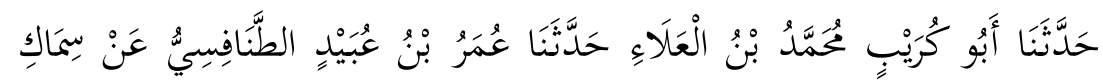

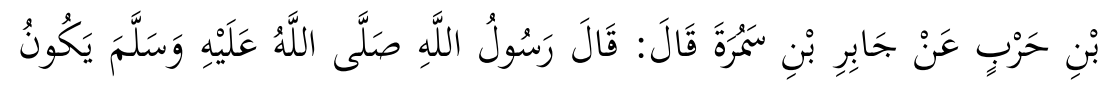




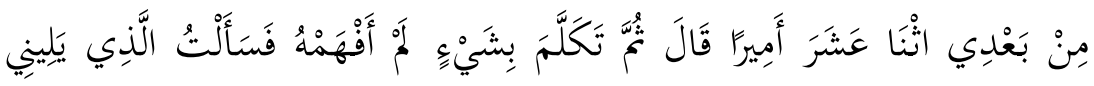

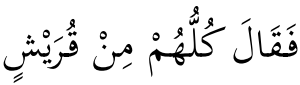

Artinya:

"Telah menceritakan kepada kami Abu Kuraib Muhammad bin al-'Ala'; telah menceritakan kepada kami Umar bin 'Ubaid Ath Thanafisi; dari Simak bin Harb dari Jabir bin Samurah berkata:Rasulullah Shallallahu 'alaihi wa salam bersabda: “Akan ada sepeninggalku dua belas pemimpin".Jabir berkata: "Kemudian beliau mengucapkan sesuatu yang tidak aku pahami lalu aku bertanya kepada yang ada dibelakangku lalu ia berkata: "Mereka semua dari Quraisy."

\section{Kitab Musnad Ahmad bin Hanbal}

Kitab Musnad Ahmadbin Hanbalpaling banyak meriwayatkan Hadits tentang Dua Belas Imam. Ada yang mengatakan 32 riwayat dan ada lagi yang mengatakan sampai 34 riwayat. Namun di bawah ini hanya disebutkan delapan riwayat, sebagai berikut:

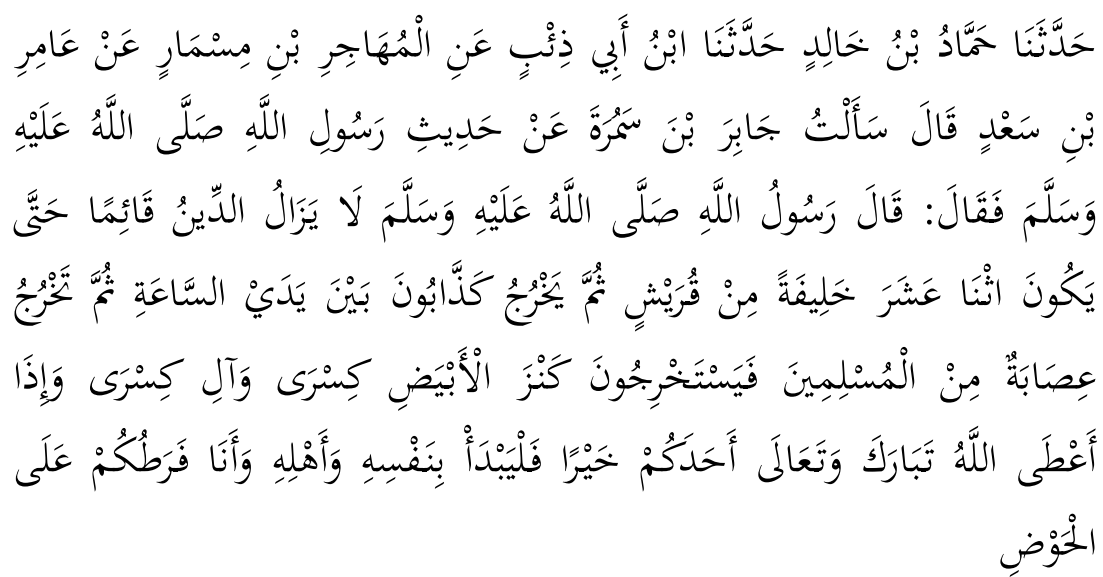

Artinya:

"Telah menceritakan kepada kami Hammad bin Khali; telah menceritakan kepada kami Ibnu Abi Dzi'b; dari Muhajir bin Mismar dari Amir bin Sa'ad ia berkata, aku bertanya kepada 
Jabir bin Samurah mengenai Hadits Rasulullah shallalahu 'alaihi wasallam. Maka ia berkata: Rasulullah shallalahu 'alaihi wasallam bersabda: "Agama ini akan selalu tegak hingga berlalu dua belas khalifah dari Quraisy, setelah itu muncullah para pendusta yaitu menjelang hari Kiamat, lalu keluarlah sekelompok kaum muslimin yang akan menundukkan istana putih Kisra dan keluarganya, apabila ada seorang hamba yang diberikan kebaikan oleh Allah Tabaraka wa Ta'ala, maka mulailah dari diri sendiri dan keluarganya, sedang aku menunggu kalian di telaga (Al-Haudh)."

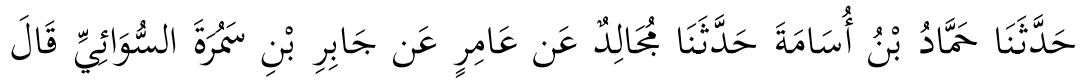

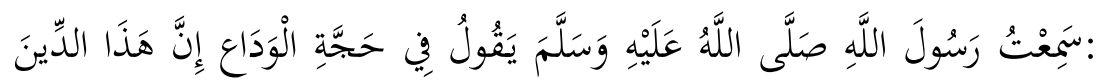

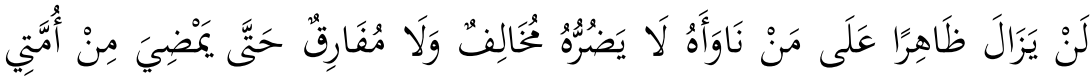

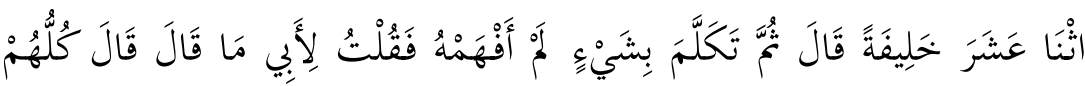

$$
\begin{aligned}
& \text { مِنْ قُرَيْشِ }
\end{aligned}
$$

Artinya:

"Telah menceritakan kepada kami Hammad bin Usamah; telah menceritakan kepada kami Mujalid dari Amir; dari Jabir bin Samurah As Suwa i i ia berkata: Aku mendengar Rasulullah shallalahu 'alaihi wasallam bersabda ketika haji wada': "Agama ini akan selalu tampak dan kuat dari yang memusuhinya, tiada akan membahayakan orang-orang yang menyelisihi atau yang memporak-porandakannya hingga berlalu dua belas khalifah dari umatku, "Lalu beliau berbicara yang tidak aku pahami, lantas aku tanyakan maksudnya kepada ayahku. Katanya beliau bersabda: "Semuanya dari Quraisy."

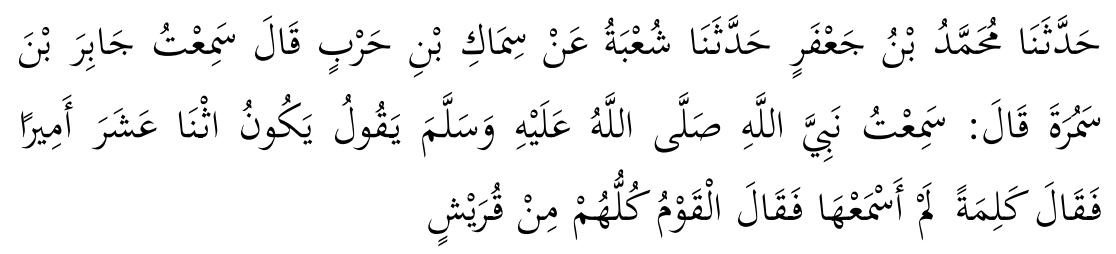


Artinya:

'Telah menceritakan kepada kami Muhammad bin Ja'far; telah menceritakan kepada kami Syu'bah; dari Simak bin Harb ia berkata: Saya mendengar Jabir bin Samurah berkata: Saya mendengar Nabi shalallahu 'alaihi wasallam bersabda: "Akan ada dua belas khalifah dari umatku".Lalu beliau bersabda beberapa kata yang aku tidak mendengarnya, lantas salah seorang menimpali: "Semuanya dari Quraisy."

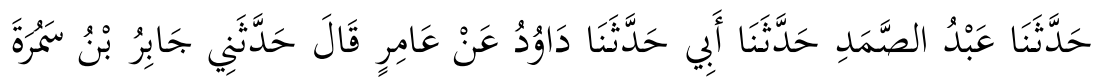

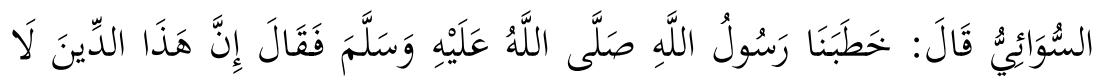

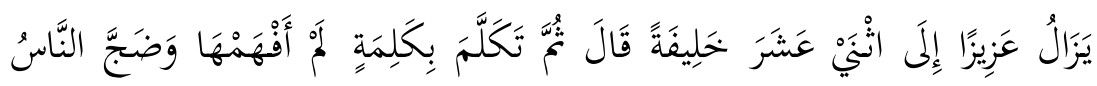

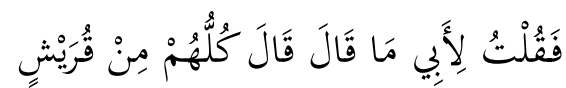

Artinya:

"Telah menceritakan kepada kami Abdussamad; telah menceritakan kepada kami Ayahku; telah menceritakan kepada kami Dawud dari 'Amir; ia berkata: telah menceritakan kepadaku Jabir bin Samurah al-Suwa $i$ ia berkata: Rasulullah shallallahu 'alaihi wasallam berkhutbah di hadapan kami, sabdanya: "Sesungguhnya dien (agama) ini akan senantiasa kokoh, hingga berlalu dua belas khalifah dari umatku, " Jabir berkata, kemudian beliau mengatakan beberapa kalimat yang aku tidak memahaminya, dan orangorang pun saling berbantahan, lalu aku bertanya kepada ayahku apa yang beliau sabdakan, ayahku menjawab: "Semuanya dari Quraisy."

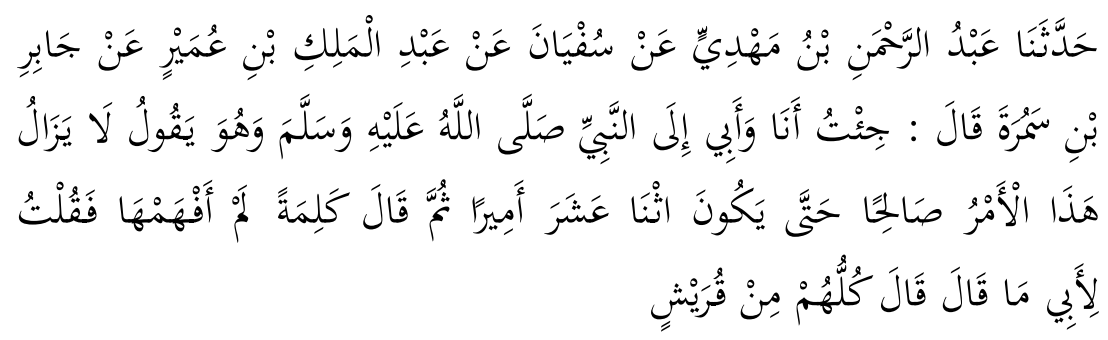


Artinya:

"Telah menceritakan kepada kami Abdurrahman bin Mahdi; dari Sufyan dari Abdul Malik bin Umair; dari Jabir bin Samurah ia berkata, "Aku dan ayahku mendatangi Nabi shalallahu 'alaihi wasallam, lalu beliau bersabda: "Urusan ini akan selalu baik dan lurus hingga berlalu dua belas khalifah dari umatku". Lalu beliau berbicara yang aku tidak paham, lantas aku tanyakan maksudnya pada ayahku, ia menjawab, beliau bersabda: "Semuanya dari Quraisy."

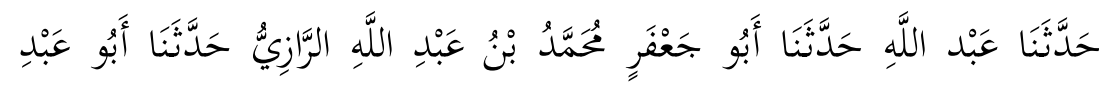

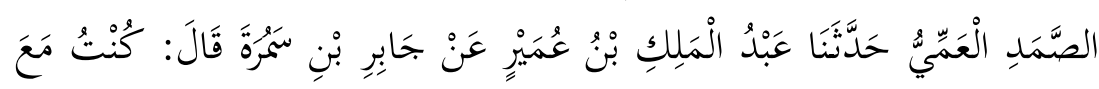

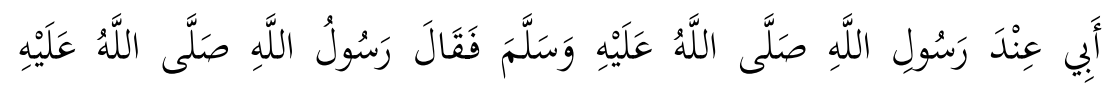

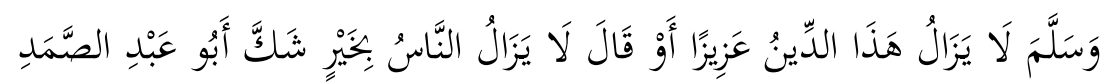

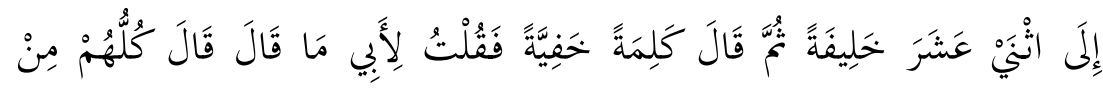
قُرَيْشِ

Artinya:

"Telah menceritakan kepada kami Abdulla; telah menceritakan kepada kami Abu Ja'far Muhammad bin Abdullah al-Razy; telah menceritakan kepada kami Abu Abdushamad al-'Ammi; telah menceritakan kepada kami Abdul Malik bin Umair; dari Jabir bin Samurah berkata, "Aku bersama ayahku menemui Rasulullah shallalahu 'alaihi wasallam, beliau bersabda: "Agama ini akan selalu kuat, atau manusia akan selalu dalam kebaikan (Abdushamad ragu) hingga berlalu dua belas khalifah dari umatku".Lalu beliau berbicara dengan pelan hingga aku pun menanyakan maksudnya pada ayahku, ia lantas menjawab, beliau bersabda: "Semuanya dari Quraisy." 


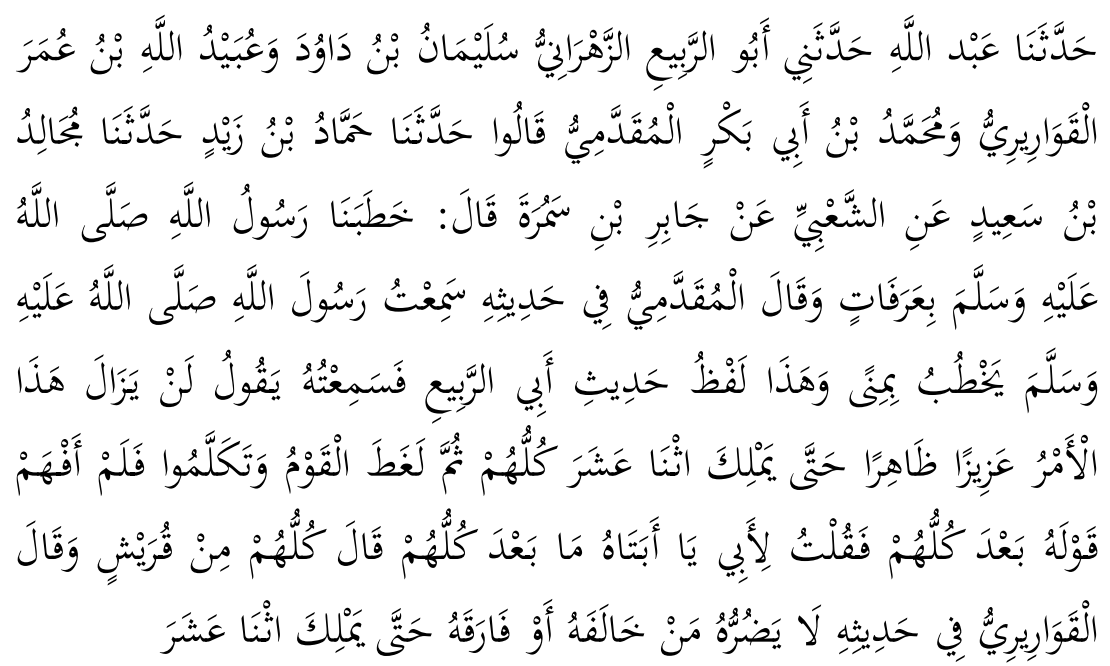

"Telah menceritakan kepada kami Abdullah; telah menceritakan kepadaku Abu Rabi' al-Zahrani Sulaiman bin Dawud dan Ubaidullah bin Umar Al Qawariri; dan Muhammad bin Abu Bakar al-Muqaddami mereka berkat; telah menceritakan kepada kami Hammad bin Zaid; telah menceritakan kepada kami Mujalid bin Sa'id; dari al-Sya'bi dari Jabir bin Samurah ia berkata, Rasulullah shallalahu 'alaihi wasallam berpidato di depan kami di hari Arafah. AlMuqaddami menyebutkan dalam Haditsnya, Aku mendengar Rasulullah shallallahu 'alaihi wasallam berkhutbah di Mina -dan ini adalah lafal Hadits Abu Rabi'--, aku mendengar Rasulullah shallallahu 'alaihi wasallam bersabda: "Agama ini akan selalu kuat dan ditolong hingga berkuasa 12 orang dari umatku, kemudian aku tidak memahami kata-kata Rasulullah shallalahu 'alaihi wasallam setelahnya kata "semuanya". Lantas aku tanyakan kepada ayahku apa yang Rasulullah katakan setelah kata 'semuanya', ayahku lantas menjawab, "Rasulullah shallalahu 'alaihi wasallam bersabda: "Semuanya dari Quraisy." Al-Qawariri menyebutkan dalam Haditsnya, "Tiada akan membahayakan yang menyelisihi, atau yang memporakporandakannya hingga berlalu dua belas khalifah." 


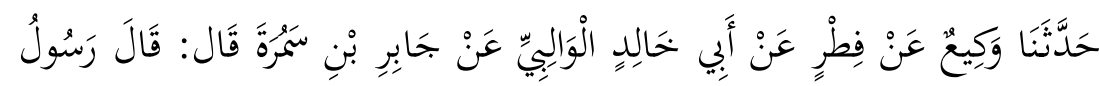

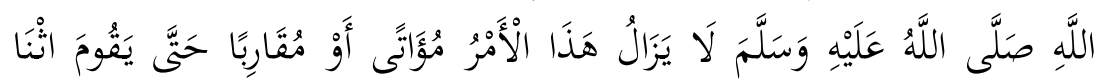

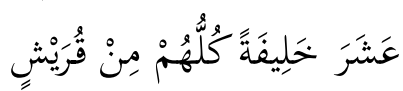

Artinya:

"Telah menceritakan kepada kami Waki'; dari Fithr dari Abu Khalid Al Walibi; dari Jabir bin Samurah berkata, "Rasulullah shallallahu 'alaihi wasallam bersabda: "Urusan ini akan selalu menang atau jaya hingga berlangsungnya dua belas khalifah, semuanya dari Quraisy.”

\section{Kualitas Hadits Dua Belas Imam}

Hadits Dua Belas Imam diterima di kalangan mayoritas ulama Ahlussunnnah wal Jamaah, khususnya ahli Hadits. Mereka menilai Hadits tersebut meskipun tidak mencapai derajat mutawatir --sebagaimana penilaian Syiah-- ia berkualitas shahih, karena diriwayatkan melalui banyak jalur sanad, dari beberapa sahabat seperti Jabir bin Samurah, Abdullah bin Mas'ud, dan Abdullah bin Amr. Ibn Hajar alHaitami, dalam kitabnya ash-Shawaiq al-Muhriqah, setelah mengemukakan Hadits tersebut mengatakan, "Semua ulama Ahlussunnah menerima ke-shabih-an Hadits ini.

Dari sisi redaksi atau lafal terdapat perbedaan dalam penyebutan istilah pemimpin dalam Hadits-Hadits di atas. Imam Bukhari meriwayatkan dengan lafal "amir", sedangkan Muslim dengan lafal khalifah dan rajulan. Abu Dawud mengunakan kata "khalifah". Al-Tirmidzi menggunakan kata "amir", dan Imam Ahmad kebanyakan menggunakan kata "khalifah" dan hanya satu menggunakan kata "amir". Tidak penulis ditemukan dengan lafal Imam.

Meskipun berbeda, ulama Ahlussunnah memandang istilah imam, khalifah, dan amir bersinonim. Dari sisi makna, semua Hadits memiliki makna substansi yang sama, yaitu Islam akan senantiasa kokoh, mulia, dan baik sampai 
dipimpin oleh dua belas imam, yang kesemuanya berasal dari suku Quraisy.

Dalam riwayat Abdullah bin Mas'ud, Masruq sebagaimana diriwayatkan Ahmad bin Hanbal, menceritakan: “Tatkala kami duduk bersama Abdullah bin Mas'ud, ia sedang membaca al-Qur'an, datang seorang yang bertanya: Pernahkah kalian bertanya pada Nabi apakah umat ini memiliki khalifah? Ibn Mas'ud menjawab: "Belum ada seorang pun bertanya sejak aku ke Irak sebelum engkau. Kami pernah menanyakan langsung pada Nabi saw. Nabi saw mengabarkan, bahwa ada sebanyak 12 orang pemimpin seperti jumlah pemimpin Bani Israil.

Dalam riwayat al-Bukhari, redaksinya hanya mengabarkan bahwa akan datang dua belas pemimpin (amir) semuanya dari suku Quraisy. Adapun al-Tirmidzi menggunakan redaksi: "Akan datang setelahku dua belas pemimpin (amir), semuanya dari suku Quraisy". Sedangkan riwayat Muslim, Abu Dawud, dan Ahmad umumnya dengan redaksi: "Agama Islam akan senantiasa kokoh atau mulia sampai dipimpin oleh 12 pemimpin (khalifah)".

Di antara riwayat-riwayat di atas ada yang memiliki keterangan tambahan yang tidak dijumpai pada riwayat lain. Seperti dalam salah satu riwayat Abu Dawud disebutkan katakata "Semuanya disepakati umat". Maksudnya dua belas pemimpin itu disepakati umat. Dalam redaksi riwayat Ahmad ada tambahan "Tidak akan membahayakan mereka orang yang menentang dan memisahkan diri dari mereka".

Dari berbagai riwayat di atas jika kita satukan, maka Hadits dua belas imam makna lengkapnya adalah: "Agama Islam setelah Nabi saw akan senantiasa kokoh dan mulia selama dipimpin oleh Dua Belas Imam yang disepakati umat. Tidak akan membahayakan mereka jika di antara umat ada yang menentang atau memisabkan diri dari kepemimpinan mereka". Meskipun diriwayatkan dengan redaksi yang agak sedikit berbeda, dari sisi kualitas para ulama sepakat, bahwa Hadits Dua Belas Imam derajatnya shabih, baik dari sisi sanad maupun matan. 


\section{Sikap dan Pemahaman Ulama Ahlussunnah terhadap Hadits}

Para ulama Hadits Ahlussunnah sepakat bahwa Hadits tentang Dua Belas Imam dapat diterima sebagai hujjah karena kualitasnya sahih. Namun terjadi perbedaan penafsiran dalam hal menentukan siapa-siapa tokoh pemimpin yang termasuk dalam Dua Belas Imam yang dimaksudkan Nabi saw. Hal ini disebabkan, sepeninggal Rasulullah, kenyataannya kepemimpinan umat Islam telah dijalankan oleh lebih dari 12 pemimpin. Apalagi jika kita kaitkan dengan Hadits lain tentang masa khilafah kenabian (khilafah nubuwwah) hanya 30 tahun. Jika ini yang menjadi tolok ukurnya maka hanya lima orang pemimpin yang berhak disebut khalifah atau imam setelah Rasulullah saw wafat, yaitu Abu Bakar selama dua tahun, Umar sepuluh tahun, Usman dua belas tahun, Ali lima tahun, dan Hasan enam bulan. Para ulama Ahlussunnah mengkategorikan khalifah pada masa tiga puluh tahun tersebut sebagai khilafah nubumwah, sebagaimana yang disebutkan dalam Hadits. Khilafahnubuwwah maksudnya adalah khilafah yang masih lurus karena masih mengedepankan manhaj Islam yang sebenarnya karena masa mereka yang masih sangat berdekatan dengan Nabi saw. Adapun setelahnya adalah masa raja-raja yang memimpin yang kemudian melahirkan dinasti-dinasti dalam Islam. Al-Nawawi telah menyebutkan hal ini ketika men-syarah Hadits Dua Belas Imam, sebagai berikut:

"Qadhi Iyadh berkata: "Dalam hal ini muncul dua permasalahan. Pertama, bahwa dalam Hadits lain disebutkan, kekhalifahan sepeninggalku adalah tiga puluh tahun, lalu akan ada kerajaan. Ini bertentangan dengan Hadits tentang 12 khalifah, karena masa 30 tahun itu hanyalah masa pemerintahan empat Khulafa al-Rasyidun. Jawabnya adalah bahwa yang dimaksud dalam Hadits tentang kekhalifahan selama 30 tahun adalah kekhalifahan kenabian (khilafah nubuwab). Sebagai penafsiran, disebutkan dalam beberapa Hadits, "Khilafah nubuwwah sepeninggalku adalah 30 tahun, 
lalu akan ada kerajaan". Dalam hal ini tidak disebutkan 12 orang.

Kedua, lebih daripada jumlah ini telah berkuasa sebagai khalifah. Ini merupakan bantahan yang keliru karena Nabi saw tidak bersabda bahwa tidak akan berkuasa kecuali 12 khalifah. Tetapi beliau bersabda:, Akan berkuasa 12 khalifah", dan jumlah orang ini telah berkuasa. Keberadaan orang lain setelah mereka tidak menggugurkan sabda tersebut. Hal ini jika yang dimaksud dengan fakta itu adalah setiap yang berkuasa. Kemungkinan yang dimaksud adalah orang yang berhak atas kekhalifahan itu dari orang-orang yang adil, dan telah berlalu orang yang diketahui di antara mereka. Jumlah ini pasti sempurna sebelum kiamat terjadi. Ada juga pendapat bahwa maknanya adalah mereka ada dalam satu masa, dan masing-masing dari mereka diikuti suatu kelompok. Qadh Iyadh berkata: "Kemungkinan hal ini telah terjadi secara aktual jika anda mencermati sejarah. Di Andalusia sendiri sudah ada tiga pemimpin di antara mereka dalam satu masa setelah 430 tahun, semuanya mengaku sebagai khalifah, dan ketika itu berada di kota yang lain khalifah kelompok Abbasiyah di Baghdad, selain orang yang mengaku hal itu pada waktu tersebut di beberapa penjuru bumi. Penakwilan ini dikuatkan dengan sabda beliau dalam kitab Muslim setelah ini, "Akan ada para Khalifah sehingga mereka menjadi banyak". Mereka (sahabat) bertanya: Apa yang Anda perintahkan pada kami? Beliau menjawab: "Membaiat yang lebih dahulu". ${ }^{19}$

Ibn Hajar al-'Asqalani mengatakan, bahwa ia belum menemukan ulama yang mengetahui secara pasti tentang maksud Hadits tersebut. Ketika memberikan penjelasan (syarh) mengenai Hadits Dua Belas Imam riwayat al-Bukhari, ia mengatakan:

${ }^{19}$ Abu Zakariya Yahya bin Syaraf Al-Nawawi, Shabih Muslim bi Syarh alNawawi, Kairo, Dar al-Taufiqiyah li al-Turats, t.th., Juz XII, h. 138 
"Saya lebih cenderung pada pendapat ketiga dari Qadhi Iyadh, karena dikuatkan dengan Hadits lain melalui beberapa sanadnya yang menyebutkan, bahwa beliau bersabda, "Semuanya disepakati oleh umat". Penjelasannya, bahwa yang dimaksud dengan kesepakatan adalah kekompakan mereka untuk membaiatnya. Yang terjadi adalah orang-orang bersepakat terhadap Abu Bakar, lalu Umar, lalu Usman, lalu Ali hingga terjadi tabkim dalam perang Shiffin. Maka ketika itu Muawiyah mengkalim dirinya khalifah. Lalu orang-orang bersepakat terhadap Muawiyah setelah mengikat perdamaian dengan Hasan. Kemudian orang-orang bersepakat terhadap putranya Yazid. Pemerintahan tidak beralih ke Husen karena ia terbunuh sebelum itu. Ketika Yazid meninggal, terjadilah perselisihan sehingga orang-orang bersepakat terhadap Abdul Malik bin Marwan setelah Ibn Zubair terbunuh. Kemudian orang-orang bersepakat teradap empat orang anaknya, yaitu Walid, Sulaiman, Yazid, dan Hisyam. Di antara Sulaiman dan Yazid diselingi Umar bin Abdul aziz. Mereka semua adalah tujuh pemimpin setelah Khulafa' al-Rasyidin. Pemimpin yang ke 12 adalah Walid bin Yazid bin Abdul Malik yang disepakati oleh orang-orang ketika pamannya Hisyam meninggal, dan dia berkuasa selama empat tahun. Kemudian orang-orang memberontak padanya lalu membunuhnya sehingga terjadi huru hara dan situasi berubah sejak saat itu. Tidak ada kesepakatan orang-orang karena Yazid bin Walid memberontak kepada anak pamannya, bahkan terjadi pemberontakan terhadapnya sebelum anak paman ayahnya, Marwan bin Muhammad bin Marwan meninggal. Ketika Yazid meninggal, saudaranya Ibrahim menggantikannya, tetapi ia dikalahkan oleh Marwan. Kemudian terjadi pemberontakan Bani Abbas terhadap Marwan sehingga dia terbunuh. Maka Khalifah pertama Bani Abbas adalah Abu Abbas al-Saffah. Kekuasaanya tidak berlangsung lama lalu saudaranya al-Mansur naik tahta. Dia berkuasa dalam waktu yang cukup lama. Namun wilayah alMaghrib al-Aqsha (Maroko) lepas dari kekuasaan mereka 
setelah keturunan Marwan menguasai Andalusia. Keluarga Marwan terus menguasai wilayah tersebut sehingga mereka menyebutnya kekhalifahan. Setelah itu, kekuasaan terlepas di semua penjuru bumi hingga kekhalifahan hanya menyisakan nama di beberapa wilayah..."20

Ibn al-Qayyim, ketika menerangkan Hadits Dua Belas Imam riwayat $\mathrm{Abu}$ Dawud mengatakan:

"Menurut Abu Hatim dan Ibn Hibban yang dimaksud Dua Belas Imam adalah khalifah empat, Muawiyah, Yazid bin Muawiyah, Muawiyah bin Yazid, Marwan bin Hakam, Abdul Malik bin Marwan, Walid bin Abdul Malik, Sulaiman bin Abdul Malik, dan yang ke dua belas adalah Umar bin Abdul Aziz. Khalifah yang terakhir ini wafat pada tahun 100 Hijriyah. Pada abad inilah agama berada di puncak kejayaan sebelum terjadi apa yang telah terjadi." 21

Abu Bakar ibn Arabi al-Maliki berkaitan dengan Hadits riwayat al-Tirmidzi di atas berkata dalam syarah-nya:

"Lalu kami menghitung dua belas imam pemimpin setelah Rasulullah saw. Maka kami menemukan Abu Bakar, Umar, Usman, Ali, Hasan, Muawiyah, Yazid, Muawiyah bin Yazid, Marwan bin Hakam, Abdul Malik bin Marwan, Walid, Sulaiman, Umar bin Abdul Aziz, Yazid bin Abdul Malik, Marwan bin Muhammad, Al-Saffah, al-Manshur, al-Mahdi, alHadi, al-Rasyid, al-Amin, al-Makmun, al-Mu'tashim, alWatsiq, al-Mutawakkil, al-Mustanshir, al-Musta'in, al-Mu'taz, al-Muhtadi, al-Mu'tadhid, al-Muktafi, al-Muqtadir, al-Qahir, al-Radhi, al-Muttaqi, al-Mustakfi, al-Muthi', al-Tha'i', al-Qadir, al-Qa'im, al-Muqtadi yang saya temui pada tahun $484 \mathrm{H}$ dan digantikan oleh al-Mustazhir Ahmad putranya dan dia meninggal pada bulan Muharram 486, lalu al-Mustazhir mengangkat putranya Abu Manshur al-Fadhl. Jika kita menghitung dua belas orang dari mereka, hitungan akan berakhir pada Sulaiman bin Abdul Malik. Jika kita

${ }^{20}$ Ibn Hajar al-Asqalani, Fath al-Bari, (Kairo: Dar al-Hadits, 1424 H/2004 M.), jilid XIII, h. 246-247

${ }^{21}$ Ibn al-Qayyim, Badzl a-Majbud syarh Sunan Abi Dawnd. 
menghitung mereka dengan pengertian kita sendiri di antara mereka hanya ada lima pemimpin, yaitu Empat Khulafaur Rasyidin dan Umar bin Abdul Aziz. Saya tidak tahu makna Hadits ini, tetapi barangkali ini penggalan dari sebuah Hadits. Telah terbukti Nabi saw bersabda: Semuanya dari suku Quraisy".22

\section{Mubriqab:}

Ibn Hajar al-Haitami dalam kitabnya al-Shawa'iq al-

"Hadits tentang Dua Belas Khalifah disepakati keshahih-annya dan diriwayatkan melalui banyak sanad. Bukhari dan Muslim serta yang lain meriwayatkannya. Di antaranya ada Hadits yang berbunyi: "Perkara ini (khilafah) akan terus menerus mulia. Mereka akan ditolong atas orang-orang yang memusuhi mereka hingga 12 khalifah, semuanya dari Quraisy". Hadits ini diriwayatkan oleh Abdullah bin Ahmad dengan sanad shabih. Ada juga Hadits yang berbunyi: Perkara ini (khilafah) akan terus menerus dalam keadaan baik". Perkara ini akan terus berlangsung sampai mereka dipimpin oleh 12 orang. Islam akan terus menerus mulia dan kuat hingga berlalu 12 khalifah yang diriwayatkan oleh Muslim. "Agama ini akan terus menerus tegak hingga ada 12 pemimpin atas kamu yang disepakati umat, diriwayatkan Abu Dawud. Dari ibn Mas'ud diriwayatkan dengan sanad hasan bahwa dia ditanya, umat ini memiliki berapa khalifah? Dia menjawab: Kami pernah menanyakan hal itu kepada Rasulullah saw. Beliau bersabda: Dua belas seperti jumlah pemimpin Bani Israil". 23

Ibn Katsir dalam kitabnya al-Bidayah wa al-Nihayah, ketika membahas Hadits tentang Dua belas Imam, mengatakan:

"Dua belas imam itu bukan yang diklaim oleh kaum Rafidhah sebagai para imam. Kaum Rafidhah mengatakan bahwa perkara manusia hanya diurus oleh Ali bin Abi Thalib

\footnotetext{
22Ibn al-Arabi, al-Tirmidzi bi Syarb Ibn al-Arabi, juz 9, h. 71

${ }^{23}$ Ibn Hajar al-Haitami, al-Shawa'iq al-Muhriqah, (Kairo Mesir: Maktabah al-Qahirah, 1385 H), Cet. II, h. 20
} 
dan putranya Hasan, dan yang terakhir menurut mereka adalah al-Mahdi al-Muntazahar yang ghaib di bangunan bawah tanah di Samarra. Dia tidak berwujud, tidak terlihat dan tidak meninggalkan jejak. Akan tetapi, Dua Belas Imam yang diberitahukan dalam Hadits adalah empat imam, yakni Abu Bakar, Umar, Usman, dan Ali, serta Umar bin Abdul Aziz yang tidak diperdebatkan di antara para imam menurut dua pendapat Ahlussunnah dalam menafsirkan Dua Belas Imam sebagaimana akan kami jelaskan setelah mengutip Hadits ini".

Kemudian beliau melanjutkan:

"Inilah yang diyakini Imam al-Baihaqi dan telah disepakati oleh Jamaah, bahwa yang dimaksud dengan Dua Belas Khalifah yang disebutkan dalam Hadits ini adalah mereka yang datang silih berganti hingga zaman Walid bin Yazid bin Abdul Malik si fasik yang tentang dirinya, kami telah kemukakan Hadits yang berisi celaan dan ancaman. Pendapat ini masih bisa diperdebatkan. Para khalifah hingga zaman Walid bin Yazid ini berjumlah lebih dari dua belas orang menurut perhitungan. Penjelasannya, para khalifah yang empat, yakni Abu Bakar, Umar, Usman, dan Ali, kekhalifahan mereka ditetapkan dengan nas Hadits, "Kekhalifahan sepeninggalku adalah tiga puluh tahun". Kemudian setelah mereka adalah Hasan bin Ali, sebagaimana terjadi Ali memberikan wasiat kepadanya dan penduduk Irak membaiatnya. Dia dan penduduk Irak berangkat untuk memerangi pasukan Syam sehingga dia mengikat perdamaian dengan Muawiyah sebagaimana ditunjukkan dalam Hadits dari Abu Bakrah dalam Shabih Bukhari. Selanjutnya adalah Muawiyah, lalu Yazid bin Muawiyah, lalu anaknya Muawiyah bin Yazid, lalu Marwan bin Hakam, lalu anaknya Abdul Malik bin Marwan, lalu anaknya Walid bin Abdul Malik, lalu Sulaiman bin Abdul Malik, lalu Umar bin Abdul Aziz, lalu Yazid bin Abdul Malik, lalu Hisyam bin Abdul Malik. Mereka berjumlah 15 orang. Lalu Walid bin Yazid bin Abdul Malik. Jika kita mengakui pemerintahan Ibnu Zubair sebelum Abdul 
Malik maka jumlah mereka menjadi 16 orang. Dengan cara perhitungan apa pun, jumlah dua belas orang itu adalah mereka yang berkuasa sebelum Umar bin Abdul Aziz. Inilah caranya menurut perhitungan tadi. Termasuk ke dalam dua belas orang ini adalah Yazid bin Muawiyah, sedangkan Umar bin Abdul Aziz tidak termasuk di dalamnya, padahal dia disepakati oleh para imam tentang keterpujiannya, dan mereka menganggap termasuk Khulafaur Rasyidin. Umat semuanya sepakat tentang tentang keadilannya dan zamannya merupakan zaman yang paling adil. Bahkan kaum Rafidhah pun mengakui hal tersebut. Jika dia berkata, saya hanya mengakui orang-orang yang disepakati oleh umat, maka menurut pendapat ini dia tidak boleh memasukkan Ali dan putranya, karena umat tidak menyepakati mereka berdua. Hal itu karena penduduk Syam tidak membaiat keduanya. Berdasarkan hal ini dapat dikatakan yang termasuk ke dalam kelompok khalifah adalah Abu Bakar, Umar, Usman, Muawiyah, kemudian Yazid, lalu Abdul Malik, lalu Walid bin Sulaiman, kemudian Umar bin Abdul Aziz. Cara ini tidak bisa diterima karena menyebabkan Ali dan putranya Hasan tidak masuk ke dalam hitungan Dua Belas Khalifah itu dan ini bertentangan dengan pernyataan para ulama Ahlussunnah bahkan Syiah". ${ }^{24}$

Al-Suyuthi dalam kitabnya"Tarikh al-Khulafa" setelah mengemukakan pendapat beberapa ulama, menyimpulkan:

"Ada pendapat yang mengatakan keberadaan dua belas imam adalah sepanjang masa sampai hari kiamat meskipun zamannya tidak berturut-turut. Al-Suyuthi mendasarkan pada riwayat Musaddad dalam musnad-nya dari Abu al-Jalad yang berkata: "Umat ini tidak binasa selagi dipimpin dua belas khalifah semuanya beramal berdasarkan petunjuk dan ajaran yang benar ". Di antara mereka dua orang dari Ahlul Bait Nabi saw. Berdasarkan riwayat tersebut dapat dikatakan Dua Belas Imam itu adalah Khulafa al-Rasyidun, Hasan,

${ }^{24} \mathrm{Abu}$ al-Fida' ibn Katsir, al-Bidayah wa al-Nihayah, Juz 6, h. 248 
Muawiyah, Ibn Zubair, Umar bin Abdul Aziz (Bani Umayyah), al-Muhtadi (Bani Abbasiyah), dan dua orang lagi yang ditunggu. Salah satunya al-Mahdi dari keluarga Nabi saw. ${ }^{25}$

Adapun dalam mazhab Syiah, Dua Belas Imam yang dimaksud adalah Ali bin Abi Thalib dan keturunannya dari jalur putranya Husain sampai yang terakhir adalah Imam Mahdi as, yaitu imam terpilih yang sejati, yang masih hidup tetapi sedang dalam masa keghaiban. Urutan imam atau khalifah menurut versi mereka adalah sebagai berikut: 1) Imam Ali bin Abi Thalib, 2) Imam Hasan bin Ali, 3) Imam Husain bin Ali, 4) Imam Ali bin Husain, 5) Imam Muhammad al-Baqir, 6) Imam Ja'far al-Shadiq, 7) Imam Musa al-Kazhim, 8) Imam Ali Ridha, 9) Imam Muhammad alJawwad, 10) Imam Ali al-hadi, 11) Imam Hasan al-Askari, 12) Imam al-Mahdi al-Muntazhar.

Susunan imamah versi di atas dianut oleh Syiah Itsna 'Asyariyah,. Adapun Syiah Ismailiyah mereka hanya sepakat sampai imam Ja'far al-Shadiq saja kemudian imam selanjutnya adalah Ismail bin Ja'far, bukan Musa al-Kazhim Adapun Syiah Zaidiyah mereka sepakat sampai Ali bin Husen saja dan imam selanjutnya adalah Zaid bin Ali, bukan Muhammad al-Baqir. Adanya beberapa versi ini juga menunjukkan, bahwa di kalangan Syiah saja tidak ada kesepakatan tentang siapa sebenarnya dua belas imam yang disebutkan oleh Hadits, baik Hadits dari jalur Sunni maupun Syiah. Ini jika kita bicara Syiah dalam ruang lingkup yang masih masih eksis hingga kini. Adapun di luar ketiga itu sudah sangat jauh penyimpangan dan penyelewengannya.

Dari beberapa pendapat ulama Sunni di atas terdapat ketidaksepakatan dalam menentukan siapa saja Dua Belas Imam itu. Al-Suyuthi dalam kitabnya al-Hawi li al-Fatawi menyatakan, bahwa tidak ada kesepakatan dalam menentukan

${ }^{25}$ Jalal al-Din al-Suyuthi, Tarikh al-Khulafa', (Beirut: Dar al-Kutub alIslamiyah, t.th.), h. 13 
siapa dua belas imam tersebut. Ibn Hajar al-'Asqalani dalam Fath al-Bari, mengutip pendapat Ibn Bathal dari al-Mahlab, bahwa tidak seorangpun yang memahami tentang Hadits ini secara pasti. ${ }^{26}$ Namun demikian Ibn Hajar mengutip pendapat Qadhi Iyadh dan ia menyetujuinya, bahwa Dua Belas Imam itu adalah yang pernah memimpin atau memerintah berdasarkan kesepakatan umat, maksudnya terdapat kekompakan mayoritas umat dalam membaiatnya. Jika ini pendirian Ibn Hajar maka dua belas imam atau khalifah tersebut adalah Abu Bakar, Umar, Usman, Ali, Hasan, Muawiyah, Yazid, Abdul Malik bin Marwan, Walid, Sulaiman, Yazid, dan Hisyam. Di antara Sulaiman dan Yazid diselingi Umar bin Abdul Aziz. Mereka semua adalah tujuh pemimpin setelah Khulafa'ur Rasyidin. Pemimpin yang ke 12 adalah Walid bin Yazid bin Abdul Malik yang disepakati oleh orangorang ketika pamannya Hisyam meninggal.

Kesimpulan Ibn Hajar di atas, karena ia menggabungkan semua riwayat yang ada, sehingga ia membatasi dengan kata-kata pemimpin (imam) tersebut disepakati oleh umat. Kesepakatan di sana bukan secara bulat atau seratus persen namun mayoritas umat. Hal ini benar adanya, karena di antara imam atau khalifah yang pernah ada, di antara mereka ada yang tidak sepakati oleh seluruh umat, tetapi hanya mayoritas. Jika pendapat ini yang dipedomani maka Umar bin Abdul Aziz tidak masuk sebagai imam dua belas, padahal dialah di antara khalifah Bani Umayyah yang paling adil dan dinilai baik masa pemerintahannya. Sedangkan sifat adil adalah ciri suatu khalifah yang ideal, yang dapat memperkokoh dan memuliakan Islam.

Qadhi Iyadh, kutip al-Nawawi, tidak setuju membatasi imam pada jumlah 12 saja, karena tidak sesuai dengan kenyataan sejarah yang melahirkan banyak khalifah. Sebagai jalan keluar, Qadhi Iyadh membagi khilafah menjadi dua kategori, yaitu khilafah nubuwwah dan yang bukan khilafah

${ }^{26}$ Ibn Hajar al-Asqalani, Op. Cit., h. 244

Pogram Pascasarjana UIN Raden Intan Lampung 
nubuwwah.Khilafah nubumwah ada lima orang, yaitu Abu Bakar, Umar ibn al-Khatthab, Usman ibn Affan, Ali ibn Abi Thalib, dan Hasan ibn Ali. Adapun Khilafah yang bukan Nubuwwah adalah mereka yang memimpin setelah itu, tidak terbatas jumlahnya. Yang terpenting mereka disepakati umat dan berasal dari suku Quraisy. Jumlah dua belas bukanlah pembatasan yang mengikat, karena dalam riwayat lain disebutkan khalifah itu banyak. Jumlah atau angka "dua belas" dalam teks Hadits bermakna, bahwa di bawah kepemimpinan dua belas imam, kaum muslimin mengalami kemajuan di bidang pemerintahan, ilmu pengetahuan dan agama.

Abu Bakar ibn Arabi al-Maliki, ketika menjelaskan Hadits tentang Dua Belas Imam riwayat al-Tirmidzi berpendapat, bahwa imam atau khalifah setelah Rasulullah sangat banyak sekali. Jika kita membatasi hanya 12 berarti akan sampai pada Sulaiman bin Abdul Malik. Hitungan Ibn al-'Arabi ini berdasarkan realita jumlah khalifah atau pemimpin setelah Rasulullah saw wafat. Jika itu yang dipedomani maka Umar bin Abdul Aziz dan yang setelahnya tidak termasuk, padahal beliau termasuk khalifah yang paling adil di kalangan Bani Umayyah. Namun menurut pendapat atau perhitungan pribadi Ibn Arabi, hanya ada lima pemimpin yang lurus (Khulafa' al-Rasyidun), yaitu Abu Bakar, Umar, Usman, Ali, dan Umar bin Abdul Aziz. Beliau meragukan akan keutuhan teks Hadits sambil mengakui tidak mengetahui maknanya secara pasti. Menurutnya mungkin itu hanya sepenggalan Hadits. Ini artinya beliau meragukan keutuhan Hadits tersebut.

Adapun hitungan al-Suyuthi sangat berbeda dengan ulama sebelumnya, seperti memasukkan Abdullah bin Zubair dan salah satu khalifah Bani Abbasiyah al-Muhtadi. Kemudian menyebutkan ada dua keluarga Nabi yang tidak disebutkan namanya. Kesimpulan al-Suyuthi ini lebih disebabkan merujuk pada riwayat Musaddad dalam Musnadnya yang tidak begitu populer.Al-Suyuthi juga cenderung pada 
pendapat bahwa para khalifah atau imam tersebut muncul secara tidak berurutan dalam satu masa.

Tidak ada keseragaman di kalangan ulama Ahlussunnah dalam menentukan siapa saja yang termasuk dua belas imam. Inilah yang menyebabkan Syiah menuduh Ahlussunnah mengalami kebingungan menyikapi dan memahami Hadits dua belas imam, padahal kualitasnya shahih. Sedangkan Syiah sendiri telah membuat penafsiran yang menurut mereka lebih sesuai dan tidak saling bertentangan. Agar tidak bertentangan dengan fakta sejarah mereka membuat konsep pembedaan antara khalifah dan imam. Menurut Syiah, imam di sana bukan dalam pengertian khalifah mengatur urusan negara atau kehidupan dunia, namun imam yang menjaga ruh agama. Imam dalam pengertian ini lebih ke bidang spiritual. Fungsi imam dalam mazhab Syiah adalah pemimpin dalam hal meluruskan agama seeorang. Keberadaan imam sejalan dan bekerjasama dengan khalifah. Inilah yang membuktikan sejak imam pertama Ali sampai imam ke 12 belas mereka membaiat bahkan ikut membantu khalifah.

Pendapat Syiah ini juga mengandung kelemahan karena di kalangan mereka sendiri juga terdapat tidakkeseragaman dalam menentukan siapa yang tergolong dua belas imam tersebut. Syiah Imamiyah berkeyakinan hak imamah berada pada Musa ibn Ja'far al-Shadiq beserta keturunannya, Syiah Zaidiyah berkeyakinan hak imamah pada Imam Zaid bin Ali dan keturunannya, sedangkan Syiah Ismailiyah berkeyakinan hak imamah pada Ismail bin Ja'far alShadiq dan keturunannya. Tiga aliran dalam Syiah tersebut memiliki versi tersendiri mengenai siapa yang tergolong dua belas imam.

Ahlussunnah tidak sepekat dengan pembedaan antara khalifah dan imam, disebabkan lafal yang terdapat dalam Hadits-Hadits sunni jelas-jelas khalifah atau amir. Menurut Ahlussunnah, khalifah itu tidak terbatas pada al-Khulafa' alRasyidun, namun siapapun yang memerintah dengan 
kesepakatan kaum muslimin maka mereka adalah khalifah meskipun mereka mewarisi kepemimpinan itu secara turun temurun sebagai raja. Karena ulama Ahlussunah membolehkan raja disebut khalifah. Bahkan sistem dinasti yang diwariskan oleh Bani Umayyah dan Bani Abbasiyah, tidak menafikan penyebutan khalifah bagi raja-raja mereka. Dan ini tercantum dalam kitab-kitab sejarah, meskipun mereka itu raja namun disebut juga khalifah, dengan syarat mereka dari keturunan Quraisy. Oleh sebab itu ketika Dinasti Turki Usmani berkuasa, pemimpin mereka disebut Sultan, bukan khalifah, karena mereka bukan dari suku Quraisy.Ahlusunnah membolehkan penyebutan khalifah digunakan untuk para pemimpin setelah al-Khulafa al-Rasyidun, meskipun mereka adalah raja, dengan syarat berasal dari suku Quraisy. Hal ini berdasarkan Hadits Nabi: "Khilafah sepeninggalku (berlangsung) selama 30 tahun, kemudian Allah memberikan kerajaan kepada siapa yang Ia kehendaki". ${ }^{27}$

Dalil lainnya adalah Hadits riwayat al-Bukhari dan Muslim dari Abu Hurairah, dari Rasulullah saw bersabda: "Bani Israil dipimpin para Nabi. Setiap kali seorang Nabi meninggal ia digantikan Nabi yang lain, dan tidak ada Nabi setelahku. Kelak akan muncul khalifah-khalifah lalu jumlah mereka kian banyak. Mereka bertanya: Apa yang anda perintahkan pada kami? Beliau menjawab: penuhi baiat khalifah pertama dan seterusnya, lalu berilah hak mereka, karena Allah akan menanyakan pada mereka tantang rakyat yang mereka pimpin.

Berkaitan dengan Hadits di atas, Ibn Taimiyah menjelaskan, sabda Nabi: "Lalu jumlah mereka kian banyak", menunjukkan bahwa khalifah-khalifah selain Al-Khulafa alRasyidun ada banyak. Sabda beliau: "Penuhilah baiat khalifah 
pertama dan seterusnya", menunjukkan terjadi perselisihan di antara mereka, sementara al-Khulafa' al-Rasyidun tidak. ${ }^{28}$

Hadits di atas juga menunjukkan pengertian bahwa akan ada penyimpangan-penyimpangan yang dilakukan oleh khalifah-khalifah setelah khalifah empat dan kelalaian mereka dalam menjalankan kewajiban agama. Namun meskipun begitu mereka tetap sebagai khalifah yang wajib di taati selagi mereka tidak kufur dan memerintahkan maksiat. Penyimpangan dan kelalaian mereka itu tanggungjawab mereka pada Allah. Yang demikian itu dengan syarat mereka masih berpedoman pada agama dan meninggikan simbolsimbol keagamaan meskipun mereka lalai dengan amalan pribadi mereka, berbuat zalim terkait keuangan dan lain sebagainya. Jika mereka tidak menegakkan agama atau melakukan penyimpangan yang menyebabkan kekafiran, maka pemimpin seperti ini tidak boleh ditaati dan kaum muslimin boleh berlepas diri atau keluar darinya. ${ }^{29}$

Pendapat Ahlussunnah ini lebih dapat diterima akal karena para khalifah itu adalah manusia biasa sehingga tidak maksum kecuali Rasulullah. Kenyataan yang terjadi pada waktu itu kaum muslimin di mata musuh-musuh yang kafir terus melejit kekuasaannya. Di zaman Bani Umayyah prestasi yang menonjol adalah keluasan wilayah Islam bertambah. Adapun di zaman Khalifah Bani Abasiyah dunia ilmu pengetahuan lebih menonjol. Jumlah dua belas bukanlah pembatasan, melainkan menunjukkan di masa dua belas imam itu kaum muslimin dalam kondisi puncak kejayaan dalam berbagai bidang.

\section{Kesimpulan}

1. Setelah diadakan takhrij terhadap Hadits-Hadits tentang Dua Belas Imam ditemukan data, bahwa Hadits-Hadits tersebut sangat banyak sekali terdapat di kitab-kitab

\footnotetext{
${ }^{28}$ Ibn Taimiyah, Majmu' Fatawa Ibn Taimiyah, Op. Cit., h. 35/20

${ }^{29}$ Ibn Hajar al-Asqalani, Op. Cit., jilid XIII, h. 11
} 
Hadits Sunni, khususnya tujuh kitab yang terkenal (alKutub al-Sab'ab). Satu riwayat dalam Shabih al-Bukhari, enam riwayat dalam Shabih Muslim, dua riwayat dalam Sunan Abi Dawud, satu riwayat dalam Sunan al-Tirmidri, dan 34 riwayat dalam Musnad Ahmad bin Hanbal. Selain tujuh kitab tersebut, Hadits-Hadits ini tercantum juga di kitab al-Mustadrak, Shabib Ibn Hibban, Mu'jam al-Thabrani, Musnad al-Bazzar, dan lain-lain. Dari sisi kualitas Hadits, para ulama Hadits telah sepakat mengenai ke-shabihannya, meskipun tidak mencapai derajat mutawatir.

2. Adapun berkaitan dengan siapa dua belas tokoh imam atau pemimpin yang disebutkan Hadits, para ulama Ahlussunnah berbeda pendapat. Ada yang menyatakan dimulai khalifah Abu Bakar sampai Khalifah Sulaiman bin Abdul Malik. Ada yang menyatakan dari Khalifah Abu Bakar sampai Khalifah Umar bin Abdul Aziz. Ada lagi yang menyatakan dari Abu Bakar sampai ke Khalifah Hasan bin Ali atau Umar bin Abdul Aziz. Meskipun mereka tidak sepakat mengenai dua belas orang yang disebutkan dalam Hadits, mereka sepakat bahwa semuanya dari suku Quraisy tanpa membatasi harus dari Bani Hasyim, sebagaimana Syiah. Sang khalifah harus disepakati oleh mayoritas umat. Jumlah dua belas imam bukanlah suatu pembatasan mutlak karena dalam Hadits-Hadits lain disebutkan, bahwa ada banyak khalifah setelah Nabi saw. Disebut dua belas orang saja karena di masa khalifah-khalifah tersebut kaum muslimin mengalamipuncak kemajuan baik di bidang ilmu, politik, maupun di bidang agama. 


\section{Daftar Pustaka}

Abu Zahrah, Tarikh al-Madzahib al-Islamiyah, Kairo, Dar al-Fkr al-Arabi, $1430 \mathrm{H} / 2010 \mathrm{M}$.

Al-Bukhari, Abu 'Abd Allah Muhammad ibn Isma'il, Shabih al-Bukhari, Semarang: Toha Putra, 1401H/1981 M.

Al-Haitami, Ahmad ibn Hajar, Shawa'iq al-Mubriqab fi Raddi 'ala Abl al-Bida' wa al-Zindiqah, Maktabah Qahirah, 1995

Al-Dumaiji, Abdullah, Konsep Kepemimpinan Dalam Islam, terj. Umar Mujtahid, judul asli "al-Imamah al-Uzhma inda Abl al-Sunnah wa al-Jamaah, Jakarta, Ummul Qura, 1437 $\mathrm{H} / 2016 \mathrm{M}$.

Al-Naisaburi, Muslim ibn al-Hajjaj Shabih Muslim, Indonesia: Maktabah Dahlan, t.th.

Al-Nawawi, Abu Zakariya Yahya bin Syaraf, Shabih Muslim bi Syarh al-Nawawi, Kairo, Dar al-Taufiqiyyah li al-Turats, t.th.

Athif Salam, Dua Napas Satu Jiwa: Titik Temu Akidah Sunnah Syiah, Jakarta, Nur al-Huda, 1436 H/2015 M

Departeman Pendidikan Nasional, Kamus Besar Bahasa Indonesia, Jakarta: Balai Pustaka, 2002.

Ibn al-Shalah, Muqaddimah Ibn Shalah fi Ulum al-Hadits, Beirut: Dar al-Kutub al-'Ilmiyyah, 1409 H/1989M.

Ibn Hanbal, Abu Abd Allah Ahmad, Musnad Imam Abmad ibn Hanbal, Beirut, Dar al-Fikr, t.th

Ibn al-Manzhur, Lisan al-Arab, Dar al-Shodiq, Beirut, $1388 \mathrm{H}$.

Ibn Khaldun, al-Muqaddimah, Dar al-Baz li al-Ansyr wa alTauzi', 1398 H.

Ibn Katsir, Abu al-Fida', al-Bidayah wa al-Nihayah, Beirut, Maktabah al- Ma'arif, $1401 \mathrm{H}$

Ibn Taimiyah, al-Siyasah al-Syar'iyah, Beirut, Dar al-Kutub alIslami, $1969 \mathrm{M}$

Majmu' Fatawa li Ibni Taimiyah, Mathabi’ Dar al-Arabiyyah, $1398 \mathrm{H}$. 
Al-Mawardi Abu al-Hasan Ali, Abkam al-Sulthaniyah wa alWilayat al-Diniyah, Kairo, Syirkah al-Quds, 2014 M.

Imam Suprayogo dan Tobroni, 2001, Metodologi Penelitian Sosial Agama, Bandung, Remaja Rosdakarya

Majdudin Muhammad bin Ya'qub Fairuz Abadi, Qamus alMubith, Beirut, Dar al-Jil, juz IV, t.th.

Muhammad Baharun, Dari Imamah sampai Mut'ah, Malang, Pustaka Bayan, 2008

M. Quraisy Shihab, Sunnah-Syiah Bergandengan Tangan : Kajian atas Konsep dan Ajaran, Jakarta. Lentera Hati, 2007

Al-Qazwini, Abu 'Abd Allah Muhammad ibn Yazid, Sunan ibn Majah, Beirut: Dar al-Fikr, 1424 H/2003 M. 